\title{
Chick Growth and Development of the Short-tailed Shearwater Puffinus tenuirostris in Tasmania
}

\author{
Nariko Oka*
}

\begin{abstract}
Chick growth of the short-tailed shearwater Puffinus tenuirostris, in a colony in Southern Tasmania was studied from mid January until the end of April 1988. Hatching took place between 10 and 25 January, with the peak occuring on 18 and 19 January. Fledging success was $35 \%$. Mortality was concentrated in the middle of the nestling period and its main cause was predation by poachers and feral cats. Emergence from burrows began, on average, on the 88.7 th night $( \pm 2.8 \mathrm{SD})$ after hatching, which corresponded to 13.9 April $( \pm 2.5 \mathrm{SD})$. After consecutive emergence for 8.8 days $( \pm 3.5 \mathrm{SD})$, they fledged on the 97.1th day $( \pm 3.3 \mathrm{SD})$ after hatching, with the peak occurring between April 23 and 29 . Hatched chicks, on average, had: $10 \%$ the body weight, $40 \%$ the tarsus length and $50 \%$ the bill (exposed culmen) length of adults and attained adult sizes during the middle of the nestling period. Chicks attained the body weight of about $15 \%$ heavier than the average adult, however, they lost $25 \%$ of the peak body weight over the last three weeks and fledged at the mean body weight $13 \%$ lighter than the average adult. As compared with the early growth of their bony organs and body weight, their feather development was delayed. Tails began to sprout at 45.5 days $( \pm 2.6 \mathrm{SD})$ after hatching and outer primaries sprouted at 34.2 days $( \pm 2.5 \mathrm{SD})$ after hatching. These parts quickly developed in the second half of the nestling period. However, in 1988 the wings and tails of the chicks did not attain adult size and continued developing at the time of fledging. The long nestling period (97 days on average) and the rotation of growth and development of bony and feather parts might be effective for ensuring survival during the nestling period, by reducing the maximum energy demand for growth.
\end{abstract}

\section{Introduction}

The short-tailed shearwater (Puffinus tenuirostris), also known in Tasmania as the muttonbird, is a Procellariiform species mainly breeding in the surrounding islands of Tasmania and migrating long distances between the waters of south eastern Australia and the northern North Pacific. The fledglings frequently die in large numbers in various waters along the migration route (Oka \& Maruyama 1986). Oka et al. (1987) considered these mortalities to be related to body growth and the amount of body lipids reserved during the nestling period. Some researchers have noted that some traits of chick growth are semiprecocial, although those of neonates are semialtricial in the Procellariiform (Nice 1962, Ricklefs 1968, 1973, Evans 1980). The most prominent characteristics widely found in the Procellariiformes which forage offshore may be: (1) the laying of one large egg, (2) a long nestling period, (3) overweight of chick followed by desertion by parents. These may be important factors for survival, enabling the birds to respond to various environments and are thought to be an adaptation to food short-

Received 31 July 1989, accepted 21 August 1989

* Yamashina Institute for Ornithology, Konoyama, Abiko, Chiba, 270-11 Japan 
ages during the nestling period (Lack 1968). These factors also seem to be linked to the mortality of migrating short-tailed shearwater fledglings. Serventy (1967), Lill and Baldwin (1983), Fitzerbert (1985) and Oka et al. (1986) reported that some of these characteristics were also prominent in the chick growth of this shearwater. However, the growth pattern adaptation of short-tailed shearwaters has yet to be thoroughly investigated from the above viewpoints.

In this paper, the exterior growth of the short-tailed shearwater is reported in detail from hatching to fledging at a colony in Southern Tasmania during 1988, and the growth characteristics of this species are discussed.

\section{Study Area}

This study was carried out at Clifton Bluff on Cape Deslacs $\left(42^{\circ} 59^{\prime} \mathrm{S}, 147^{\circ} 33^{\prime} \mathrm{E}\right)$ $22 \mathrm{~km}$ southeast of Hobart in Southern Tasmania, Australia, from mid January to the end of April 1988 (Fig. 1).

The colony at Clifton Bluff is one of about fifteen colonies on mainland Tasmania

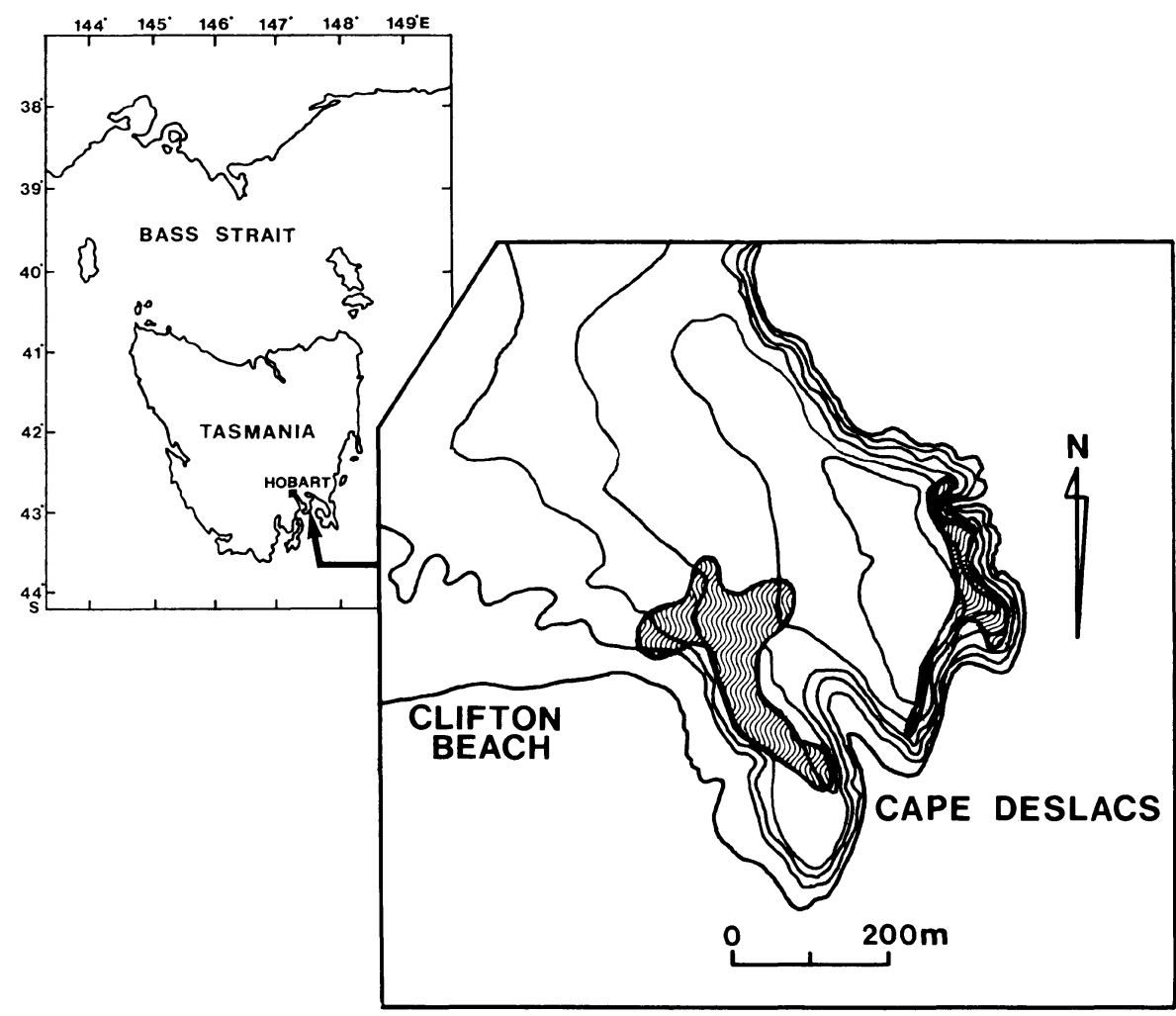

Fig. 1. The study area. Burrows of short-tailed shearwater are distributed in the shaded area. The contour-lines at the interval of $10 \mathrm{~m}$ in altitude are based on the 1: 25000 map produced by the Lands Department of Tasmania, 1985. 
and it is also one of the forty known colonies located in the most southern breeding areas for this shearwater (Naarding 1981). The cool current affects these waters throughout the year.

The colony was about 4 ha in size, situated on the coastal tableland fringed by steep cliffs rising from 30 to $40 \mathrm{~m}$ above sea level. This tableland was mostly covered by a thick layer of sand or sandy soil. This provides the shearwaters with its favoured breeding habitat for making burrows $60-130 \mathrm{~cm}$ deep. The colony was divided into two areas $200 \mathrm{~m}$ apart (Fig. 1) and was covered with ice plant Tetragonia implexioma, pig face Carpobrotus rossii, coastal salt bush Rhagodia baccata, silver tussock Poa poiformis and marram grass Ammophila arenaria. Footpaths traversed the west area to the look out point on the cliff. The burrow density averaged $0.5 / \mathrm{m}^{2}$ (range: $0.3-$ $\left.1.5 / \mathrm{m}^{2}\right)$. The colony has been designated a wildlife sanctuary by the Tasmanian Government since 1987, and "muttonbirding," that is, removing chicks for food is prohibited. Before 1986 people had legally harvested older chicks almost every year.

The climate of Southern Tasmania in 1988 was characterized by a dry summer. Monthly rainfall in Hobart averaged $25 \mathrm{~mm}$ during the study period, which was half of the long-term average. The air temperature ranged from $24^{\circ} \mathrm{C}$ in January to a low of $19^{\circ} \mathrm{C}$ in April, about $2^{\circ} \mathrm{C}$ warmer than the usual summer average (Bureau of Meteorology, Australia, 1975).

\section{Methods}

\section{Weighing and measuring chicks}

In deep burrows, I dug a pit through the ceiling of the burrow to take out the chick. Each pit was then covered with a board. Each burrow was numbered using a short stick pegged near its entrance for identification. I used the grass to hide them from people. To avoid rejection of eggs by parents, I began egg and chick handling after mid January when most of the eggs were about to hatch. Chicks were ringed with a monel band for individual identification in early April before they repeatedly emerged from burrows at night.

A total of 68 identified chicks were handled during the study period. I recruited new chicks when some chicks marked were lost by predation or by other factors. Twenty five ( $\pm 3.8 \mathrm{SD}$ ) (range 16-32) out of 68 chicks were weighed daily before dusk and after dawn, with a $100 \mathrm{~g}$ copper balance to the nearest $1 \mathrm{~g}$ for chicks up to a few days old and with a $1 \mathrm{~kg}$ pesola spring balance to the nearest $5 \mathrm{~g}$ for chicks afterwards. Chick weight data used in this study are those obtained before dusk when food in the stomach was mostly digested. To determine whether a parent entered its burrow and whether late nestlings emerged from burrows, a $\mathrm{Y}$ shaped stick about $15 \mathrm{~cm}$ long was pegged at the mouth of each burrow every dusk.

The lengths of the exposed culmen, tarsus, wing, outer primary and tail of the identified 68 chicks in total were measured to the nearest $0.1 \mathrm{~mm}$ for the first two parts and $1.0 \mathrm{~mm}$ for the remainder using a slide caliper or a steel ruler every three days. I did not measure the outer primary of chicks older than 70 days because of the difficulties in 
Table 1. Regression equations for lengths (in $\mathrm{mm}$ ) of the wing, outer primary, tail, bill and exposed culmen and for body weight (in $\mathrm{g}$ ) used to estimate the age of shorttailed shearwater chicks at Clifton Bluff in Southern Tasmania in 1988.

\begin{tabular}{lllcl}
\hline \multicolumn{1}{c}{ Body parts } & Equations* & & $\begin{array}{c}\text { Correlation } \\
\text { Coefficient }\end{array}$ & P \\
\hline Wing & $y=2.578 x-4.157$ & $x \geqq 10$ & 0.98 & $<\mathbf{0 . 0 1}$ \\
Outer primary & $y=3.32 x-115.30$ & $x \geqq 35$ & 0.97 & $<\mathbf{0 . 0 1}$ \\
Tail & $y=1.75 x-71.07$ & $x \geqq 45$ & 0.96 & $<0.01$ \\
Exposed culmen & $y=0.24 x+17.13$ & $x \geqq 1$ & 0.95 & $<0.01$ \\
Tarsus & $y=0.56 x+22.38$ & $x \geqq 1$ & 0.97 & $<0.01$ \\
Body weight & $y=6.3 x+156.2$ & $x \geqq 5$ & 0.83 & $<0.05$ \\
\hline
\end{tabular}

* $x$ : age in days, $y$ : size of each body part.

measuring accurately in a short time without creating a disturbance which may stimulate the early fledging.

These attribute values were also obtained from 45 breeding adults at the same colony from November to March in 1983 and 1985. The adult body weights do not include stomach content.

\section{Aging}

Hatching dates were known for 19 chicks from the 68. The ages of the remaining chicks were estimated by regression equations involving the relationship between the age and five body parts; exposed culmen, tarsus, wing, outer primary and tail lengths of the 19 known age chicks (Table 1). Since all of these parts, except for body weight, are less susceptible to nutritional conditions, some body parts have been used to reliably estimate the age of nestlings of other species (Dyrca 1974, Ricklefs et al. 1980, Bechard et al. 1985 and others). As correlation coefficients (except for body weight) were very high ( $\mathrm{r} \geqq 0.95)$ also in this study, the age of chicks were determined as the average of the ages calculated from the above regression equations. Chick ages added to the sample at the middle nestling period were estimated using the equations for wing, outer primary and tail lengths, because the culmen and tarsus had almost reached adult size by this time. On the other hand, the outer primary and the tail were useful for aging older chicks because they sprouted in the middle nestling period and tail, wing and outer primary continued growing until fledging.

The distribution of hatching dates was obtained from 19 chicks of known age and 18 chicks of estimated age added to the studied samples before mid February.

\section{Curve fitting}

To know the growth characteristics of body parts and to calculate the growth rate for the population, the daily average values of each body part were fitted to the logistic and Gompertz equations.

Both formulas are as follows:

the Gompertz equation is $Y(t)=a \cdot \exp \left[-b \cdot \exp ^{(-k t)}\right]$ and

the logistic equation is $Y(t)=\frac{a}{1+b \cdot \exp ^{(-k t)}}$, 
where $a$ is the asymptotic value and $b$ and $k$ are the constants estimated by the linearization method. The mean body weight decrease prior to fledging was regressed using an exponential curve. The fitting of those equations was based on the least-squares method, using a computer.

\section{Results}

1. Hatching dates

The 37 studied chicks ( 19 known and 18 estimated age chicks) hatched over a period of 15 days between January 10 and $25.60 \%$ of the hatchings were concentrated in the four days between January 16 and 19 with the peak dates being January 18-19 (Table 2).

2. Mortality during nestling period and fledging success

Of the 68 chicks examined, only $24(35 \%)$ fledged (Table 3$)$.

Table 4 shows the relationships between age and mortality frequency and factors during the nestling period. Mortality caused by predators ranked first among the mortality factors, being at $73 \%$ of the whole. The distribution between feral cats and poachers was almost even, $27 \%$ and $25 \%$, respectively. The remaining $27 \%$ included various causes; illness, cold by saturation, burrow destruction due to trampling by sheep, disappearance probably due to my disturbance and other unknown reasons.

Mortalities from disease were only found in younger chicks. Mortalities due to predators were concentrated in the period between 50 and 75 days of age (Table 4), being in March.

Table 2. Frequency of hatching dates for short-tailed shearwater chicks at Clifton Bluff, Southern Tasmania in 1988.

\begin{tabular}{cccc}
\hline \multicolumn{2}{c}{ Date } & No & $\%$ \\
\hline January & $10-11$ & 1 & 2.7 \\
$12-13$ & 2 & 5.4 \\
$14-15$ & 3 & 8.1 \\
$16-17$ & 9 & 24.3 \\
$18-19$ & 13 & 35.2 \\
$20-21$ & 6 & 16.2 \\
$22-23$ & 2 & 5.4 \\
$24-25$ & 1 & 2.7 \\
\hline Total & 37 & 100.0 \\
\hline
\end{tabular}

Table 3. Fledgling success and mortality rate for short-tailed shearwater chicks at Clifton Bluff, Southern Tasmania in 1988.

\begin{tabular}{llr}
\hline \hline & No & $\%$ \\
\hline No. fledglings & 24 & 35.3 \\
No. chicks dead before fledging & 44 & 64.7 \\
Total & 68 & 100.0 \\
\hline
\end{tabular}




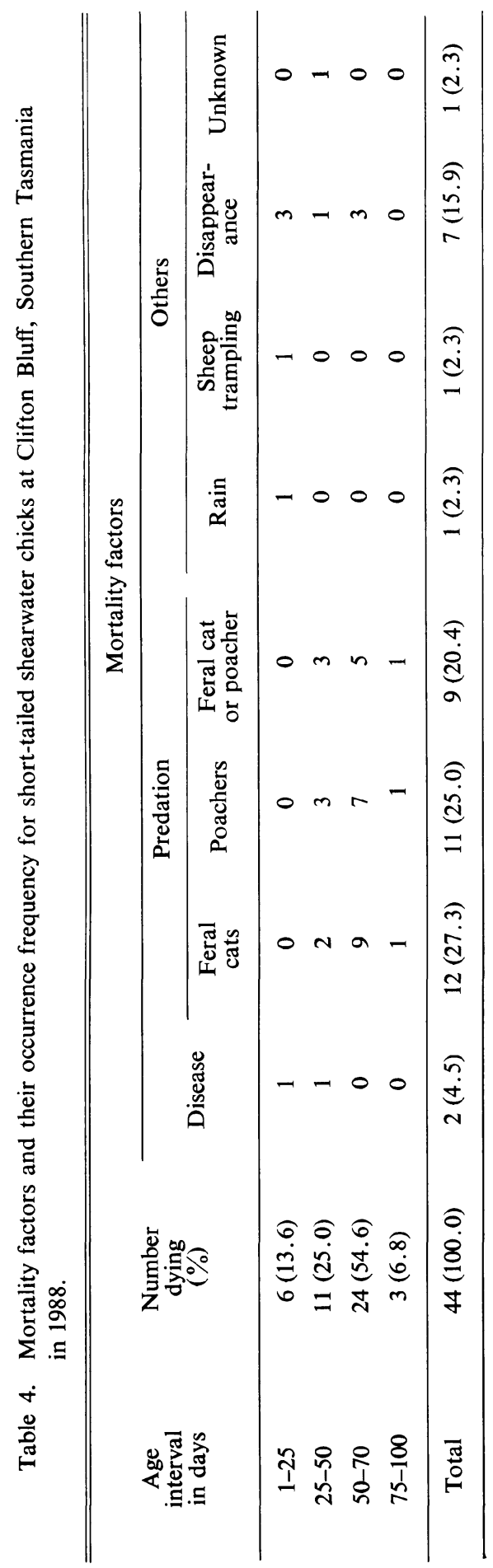




\section{Fledging period}

Chicks began emerging from their burrows on April $13.9( \pm 2.5 \mathrm{SD})(\mathrm{n}=24)$ (range: April 11-20), 88.7 nights ( $\pm 2.8 \mathrm{SD}$ ) (range: $84-95$ nights) after hatching, and continued for 8.8 nights $( \pm 3.5 \mathrm{SD})$ (range: $2-17$ nights) before fledging.

Twenty-three out of 24 fledglings departed from their burrows between April 15 and 29 (Table 5-1) with the mean date being April 23.1 ( $\pm 3.9 \mathrm{SD}$ ). One chick, 103 days old, remained unfledged on April 30. $68 \%$ of fledgings were concentrated during the seven days between April 23 and 29 (Table 5-1). The mean fledging age was 97.1 days $( \pm 3.3 S D)$ (range: $91-103+$ days) (Table $5-2$ ). $71 \%$ of chicks fledged between 94 and 99 days of age.

\section{Growth}

\section{Weight}

The changes in chick body weight by age and date during all the nestling periods and presented in Figure 2 with the mean body weights at fledging and adults. Mean hatching weight was $59.2 \mathrm{~g}( \pm 2.3 \mathrm{SD})(n=19)$, about $10 \%$ of the adult weight of $584.4 \mathrm{~g}$ $( \pm 45.7 \mathrm{SD})(n=44)$ (Table 6$)$. Body weight growth was divided into three stages. The first stage was a weight increase which lasted 56 days after hatching. This increase stage occurred between January 18 and March 12 . The second was a peak plateau stage which was found between 57-83 days of age and lasted four weeks, when chick body weight reached about $650-680 \mathrm{~g}$. This "overweight" plateau stage, which exceeded the adult body weight, approximately corresponded to the period between March 13 and April 9. At the end of this stage a marked fluctuation was observed between April 1 and 9 , corresponding to 73 to 82 days of age. The last one was characterized by continuous weight decrease for two weeks from 84 days of age toward fledging. This decrease stage approximately corresponded to the period between April 10 and 30 . At the end of this period, around 91 and 100 days of age and after April 24, small increases occurred. This was due to the heaviest chick, which was left after the fledging of the lighter chicks.

The weight growths by age and date during the first and second stages were better fitted to the Gompertz curves with the error mean square (EMS) of 668 and 717 than to the logistic curves with EMSs of 1,791 and 1,750 , respectively. The asymptote

Table 5. Frequency of fledging by date (1) and age (2) for short-tailed shearwater chicks at Clifton Bluff, Southern Tasmania in 1988.

(1)

\begin{tabular}{rlrr}
\hline & Date & No & $\%$ \\
\hline April & $15-19$ & 4 & 16.7 \\
& $20-22$ & 3 & 12.5 \\
$23-25$ & 10 & 41.7 \\
& $26-29$ & 6 & 25.0 \\
& 30 afterwards & 1 & 4.2 \\
\hline Total & 24 & 100.0 \\
\hline
\end{tabular}

(2)

\begin{tabular}{crc}
\hline \hline Age (days) & No & $\%$ \\
\hline $91-93$ & 3 & 12.5 \\
$94-96$ & 7 & 29.1 \\
$97-99$ & 10 & 41.7 \\
$100-102$ & 3 & 12.5 \\
$103+$ & 1 & 4.2 \\
\hline Total & 24 & 100.0 \\
\hline
\end{tabular}




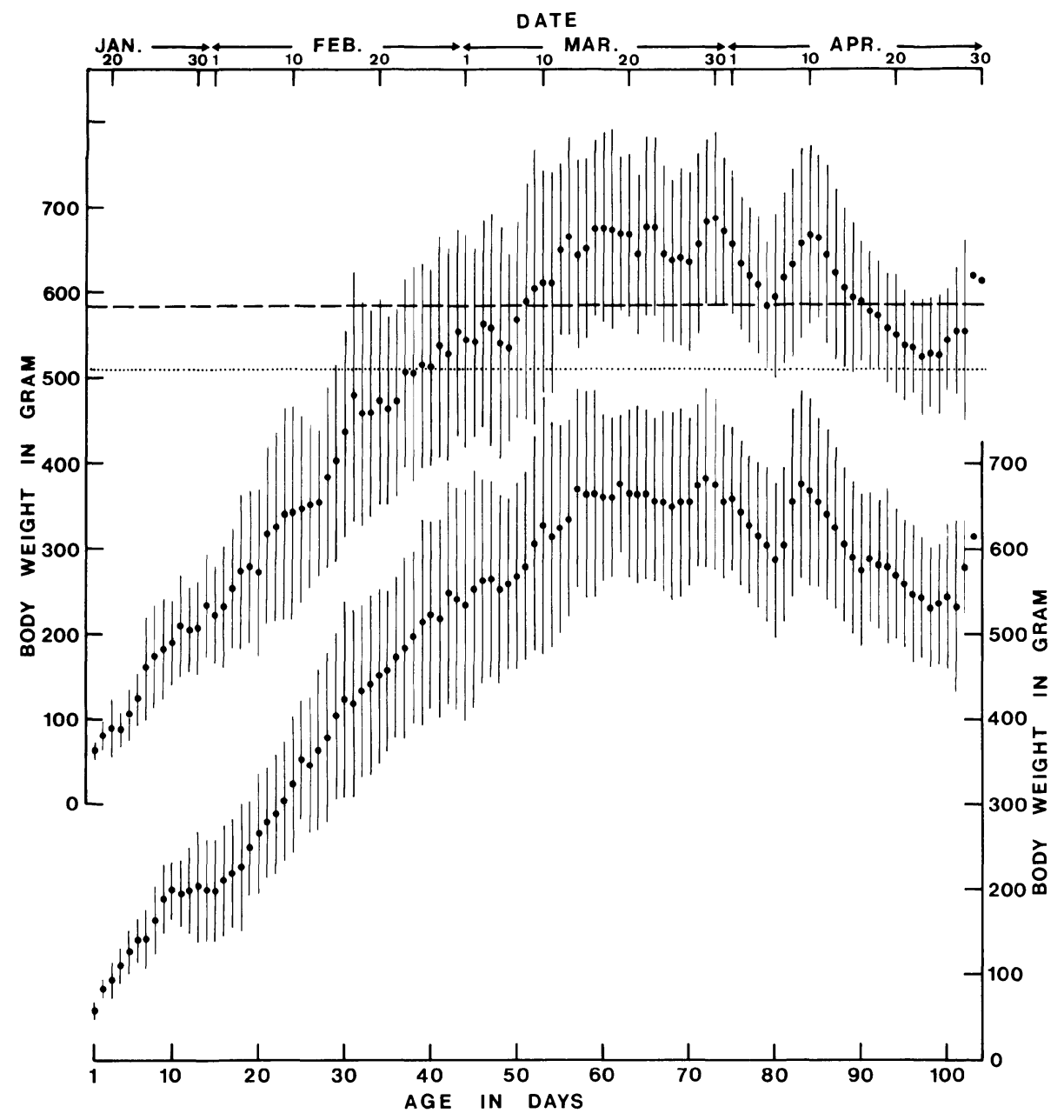

Fig. 2. Changes of mean body weight for short-tailed shearwater chicks between mid January and the end of April 1988 (a) and from hatching to fledging (b) at Clifton Bluff in Southern Tasmania. Vertical lines represent standard deviations. The dashed line represents the mean body weight for the adults and the dotted line represents that for chicks at fledging.

values of the Gompertz curves by age and date, $700 \mathrm{~g}$ and $684 \mathrm{~g}$ respectively, were theoretically regarded as the maximum weights during nestling. Both values were within the SD ranges of the actual values and were, as well as the actual mean values, about $15 \%$ heavier than the mean adult weight. The constant " $k$ "s of the Gompertz formula both for age and date were 0.05 , respectively (Table 7). The weight changes by age and date at the decrease stage closely fitted the exponential curves $(r=0.96,0.97$ respectively) when avoiding the data of the extremely heavy chicks with ages of older than 100 days. The weight at fledging was $508.7 \mathrm{~g}( \pm 71.6 \mathrm{SD})$, about a $25 \%$ decrease from 
Table 6. Body weight and lengths of adult short-tailed shearwaters collected at Clifton Bluff, Southern Tasmania.

\begin{tabular}{llccc}
\hline \hline & & $\bar{x}$ & SD & $n$ \\
\hline Body weight* & $(\mathrm{g})$ & $584.4 \pm 45.7$ & 44 \\
Tarsus length & $(\mathrm{mm})$ & $51.49 \pm 1.47$ & 45 \\
Culmen length & $(\mathrm{mm})$ & $31.92 \pm 1.29$ & 44 \\
Wing length & $(\mathrm{mm})$ & $266.9 \pm 6.6$ & 45 \\
Tail length & $(\mathrm{mm})$ & $82.4 \pm 2.5$ & 45 \\
\hline
\end{tabular}

* The value without stomach contents.

Table 7. Regression formula and constants of the external body growth of short-tailed shearwater chicks at the Clifton Bluff, Southern Tasmania in 1988.

\begin{tabular}{lccccc}
\hline \hline & $\begin{array}{c}\text { Asymptote } \\
\text { "a" }\end{array}$ & $\mathrm{b}$ & $\mathrm{k}$ & $\begin{array}{c}\text { ak/e or } \\
\mathrm{ak} / 4^{*}\end{array}$ & $\begin{array}{c}\text { Fitted } \\
\text { Form** }\end{array}$ \\
\hline Body weight by date (g) & 683.9 & 2.193 & 0.055 & 13.88 & $\mathrm{G}$ \\
Body weight by age (g) & 699.9 & 2.054 & 0.051 & 13.17 & $\mathrm{G}$ \\
Exposed culmen by age (mm) & 32.66 & 0.873 & 0.037 & 0.30 & $\mathrm{~L}$ \\
Tarsus by age (mm) & 52.34 & 1.662 & 0.071 & 0.93 & $\mathrm{~L}$ \\
Wing by age (mm) & 323.0 & 11.533 & 0.041 & 3.31 & $\mathrm{~L}$ \\
Outer primary by age (mm) & 134.4 & 4.580 & 0.096 & 4.76 & $\mathrm{G}$ \\
Tail by age (mm) & 82.3 & 4.799 & 0.099 & 3.00 & $\mathrm{G}$ \\
\hline
\end{tabular}

* ak/e and ak/4 represent growth rates at inflection point, for the Gompertz and the logistic curves, respectively.

** $\mathrm{G}$ and $\mathrm{L}$ represent the Gompertz and logistic curves respectively.

the peak weight and about $75 \mathrm{~g}(13 \%)$ lighter than the mean adult weight. $87.5 \%$ of the chicks fledged at weights lighter than adults.

Daily increase of chick body weight was estimated by differentiating the above formula with respect to time $(\mathrm{t})$. The growth rate increased from $9 \mathrm{~g}$ per day just after hatching to a maximum of $13 \mathrm{~g}$ per day at 15 days of age (Fig. 3-a), and then decreased toward the end of the plateau stage. In the decrease stage, the body weight loss per day was from $10 \mathrm{~g}$ to $7 \mathrm{~g}$ at fledging.

\section{Tarsus and exposed culmen length}

Chicks hatched at about $40 \%$ of the mean adult tarsus length of $51.49 \mathrm{~mm}$ $( \pm 1.47 \mathrm{SD})(n=45)$ (Table 6$)$. The data of tarsus development was better fitted to the logistic curve $(E M S=0.48)$ than to the Gompertz curve $(E M S=2.99)$. During the first 30 days after hatching the tarsus developed rapidly with daily maximum development of $0.9 \mathrm{~mm}$ at a week of age. It firstly reached the adult length at 48 days of age ( $t$-test, $p<0.01$ ) (Figs. 3-b, 4-a). The asymptote value, $52.3 \mathrm{~mm}$ (Table 7), well corresponded to the actual mean values of chicks at fledging and adults.

Chicks hatched at about $50 \%$ of the adult exposed culmen length of $31.92 \mathrm{~mm}$ $( \pm 1.29 \mathrm{SD})(n=44)$ (Table 6$)$. The growth data of the exposed culmen was also better fitted to the logistic curve (EMS $=0.307$ ) than to the Gompertz curve (EMS $=0.333$ ). It developed most rapidly around hatching with a maximum growth rate of $0.3 \mathrm{~mm}$ 


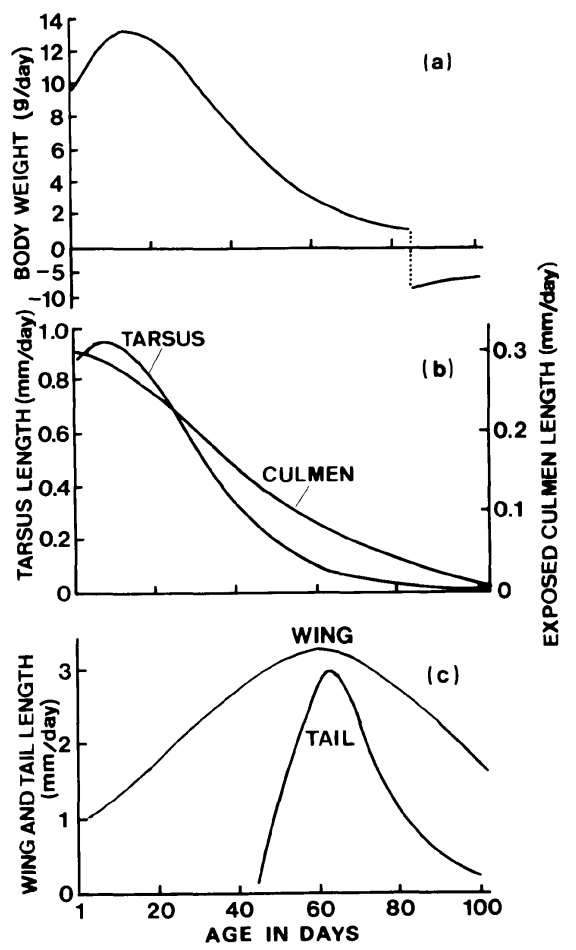

Fig. 3. Growth rate changes of body weight and length of curves for the following attributes of tarsus, exposed culmen, wing and tail for short-tailed shearwater chicks at Clifton Bluff in Southern Tasmania from hatching to fledging in 1988.

and continued developing for the first three weeks (1-20 days of age) with an increase of more than $0.25 \mathrm{~mm}$ per day (Figs. 3-b, 4-b). It reached the adult size at 65 days of age ( $t$-test, $p<0.01)$. The asymptote value, $32.7 \mathrm{~mm}$, well corresponded to both the mean value of chicks at peak and of adults.

Wing, outer primary and tail length

Chicks hatched at about $10 \%$ of the adult wing length, $266.9 \mathrm{~mm}$ ( $\pm 6.6 \mathrm{SD}$ ) $(n=45)$ (Table 6). The data for the wing growth were better fitted to the logistic curve $(\mathrm{EMS}=48.9)$ than to the Gompertz curve $(\mathrm{EMS}=305.0)$. However, the asymptote value, $323 \mathrm{~mm}$, abnormally exceeded the wing length of adults, though the calculated value at 100 days of age, $271.1 \mathrm{~mm}$, was near the actual value of chicks at the same age, $260.0 \mathrm{~mm}( \pm 9.3 \mathrm{SD})$ and to that of adults. Thus, in regard to the wings, although the logistic curve followed comparatively well the development from hatching to fledging, the asymptote value can not be regarded as the theoretical maximum. The wings grew slowly for the first 40 days and then more rapidly when the outer primary began to develop. Growth was most rapid between 40 and 80 days of age with a maximum increase of $3.3 \mathrm{~mm}$ per day at around 60 days (Figs. 3-c, 4-c). At the end of the nestling period, around 95 and 100 days of age, the mean values exceeded it of fledgings. This 

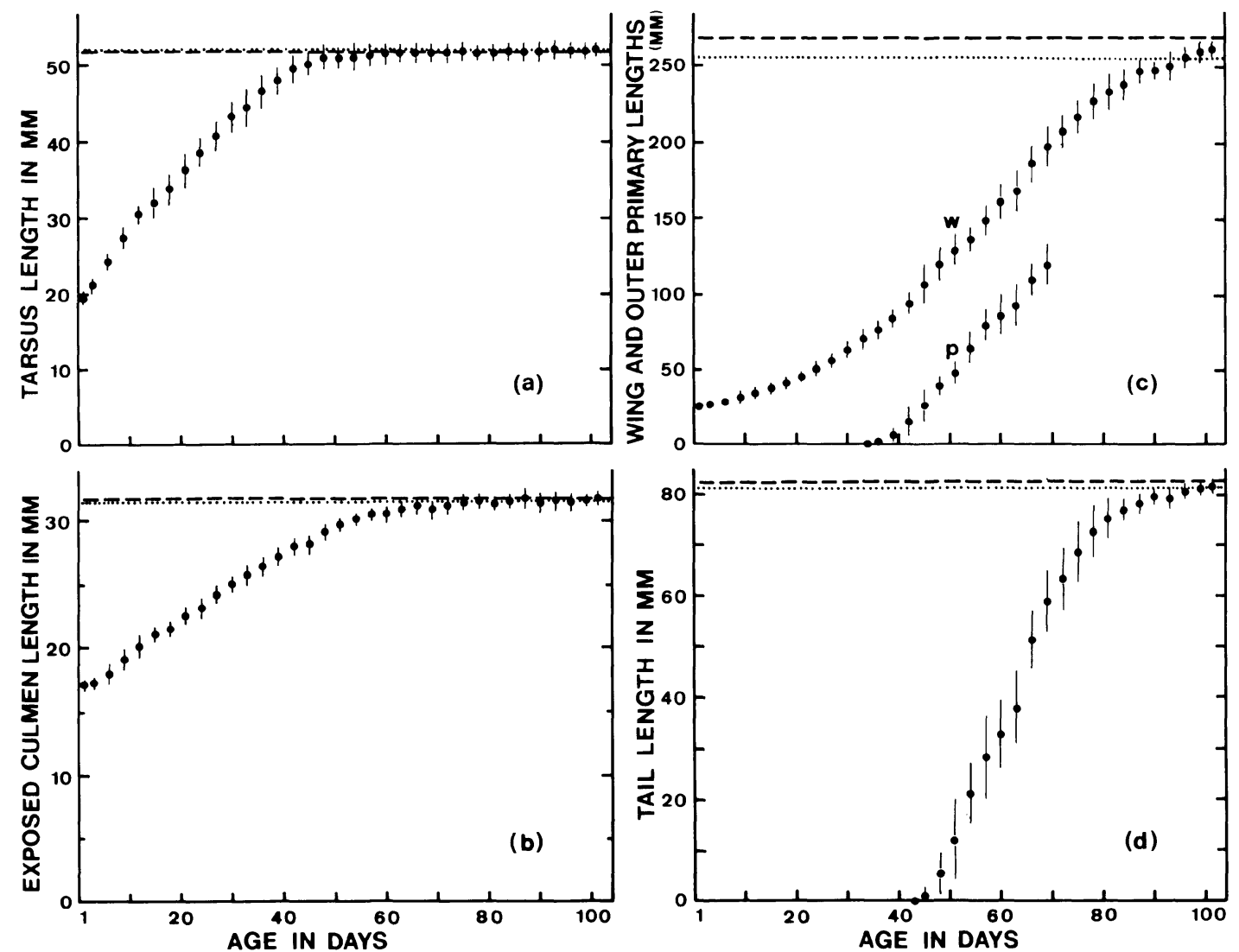

Fig. 4. Growth of tarsus, exposed culmen, wing (w) and outer primary (p) and tail of short-tailed shearwater chicks from hatching to fledging at Clifton Bluff in Southern Tasmania in 1988. Vertical lines represent standard deviations. The dashed line represents the means for adults, and the dotted line represents those of chicks at fledging.

was due to the well developed chicks, remaining after the fledging of under-developed chicks. Chicks fledged with wings $5.0 \%$ shorter on average than those of adults $(t$-test, $p<0.01$ ), and wings continued developing at a rate of $1.6 \mathrm{~mm}$ per day at fledging.

The outer primaries began to grow at 34.2 ( $\pm 2.5 \mathrm{SD}$ ) days of age (Fig. 4-c) and the feather tips sprouted at 40-45 days of age. The data closely fitted the Gompertz curve $(E M S=12.7)$ as compared with the logistic curve (EMS=240.6). The length of the outer primary increased at the maximum rate of about $4.8 \mathrm{~mm}$ per day (Table 7) with a high correlation to the wing length growth $(r=0.97, p<0.01)$.

The data for tail growth also far better fitted to the Gompertz curve $(\mathrm{EMS}=4.8)$ than the logistic curve (EMS $=157.8)$. The tail began last to come out at $45.5( \pm 2.6 \mathrm{SD})$ days of age and grew quickly over the next 35 days with a maximum growth rate of 3.0 $\mathrm{mm}$ per day at around 60 days of age, the same period as maximum wing development 

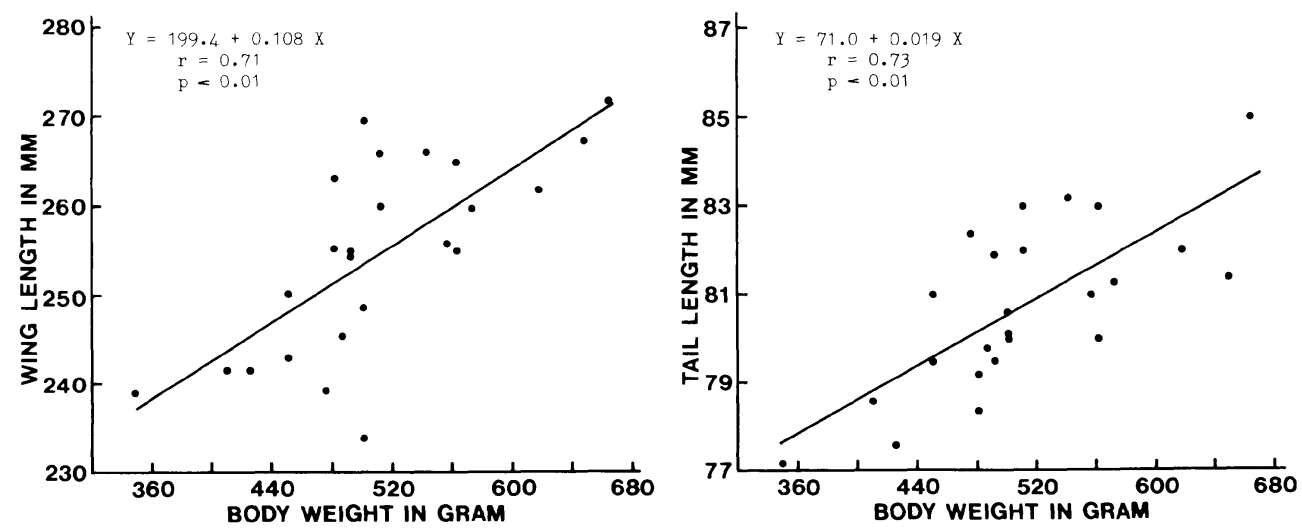

Fig. 5. Relationship between the sizes of the tail and wing and the body weight of shorttailed shearwater chicks at fledging in 1988.

(Figs. 3-c, 4-d). Although the asymptote value, $82.3 \mathrm{~mm}$, closely corresponded to the mean value of adults, chicks fledged with tails averaged $2 \%$ shorter than those of adult, $82.4 \mathrm{~mm}( \pm 2.5 \mathrm{SD})(n=45)(t$-test, $p<0.01)$ (Table 6$)$.

5. Relationships between the sizes of the tail and wing and the body weight at fledging

Regressive relations were found between the sizes of the tail and wing and the body weight at fledging (Fig. 5). It was thus concluded that the sizes of those parts were longer with greater body weight at fledging, and that lighter chicks fledge $\mathrm{d}$ with shorter flying organs. This suggests that those shorter organs also develop after fledging.

\section{Egg tooth and down shedding}

Egg tooth loss was variable, disappearing at an average $17.2( \pm 3.0 \mathrm{SD})$ days of age $(n=14)$ (range: $12-24$ days of age).

Second down began to be shed at about 70 days as feathers appeared, and it was almost gone when the chicks were fully feathered at about 90 days of age. There was some variation in where shedding began first, but mostly the order was: around the bill, and then followed by throat, head, chest, back, wing, tail, ramp, lower abdomen, neck, side and central abdomen.

\section{Discussion}

Ricklefs $(1968,1973)$ indicated that the constant $k$ of regression formulas such as the logistic and Gompertz ones corresponded to the overall growing speed peculiar to each attribute. The $k$ value for the body weight of short-tailed shearwater chicks in this study was within the range of the Procellariiformes shown by Ricklefs (1973). The nestling periods of shearwaters are usually more than twice as long as those of precocial and semiprecocial species with similar adult body weights. The nestling period of about 100 days for short-tailed shearwaters in this study was within the range of the shearwater species. This prolonged growth of Procellariiformes has been explained 
as contributing the reduction of energy requirements for intermittent meals by parents (Lack 1968), even though the total growth energy requirement might not decrease (Ricklefs 1980). This energy conservation was found also in short-tailed shearwater chicks; the tarsus and culmen preceeded the wing and tail in development. Further, this rotation may provide the chicks other merits and demerits for survival.

The development of the tarsus and culmen was more closely fitted to the logistic equations than to the Gompertz. The high correlation of those two bony parts to the logistic curves was probably due to prenatal development at a slow speed. Prenatal development and the early completion of the bill after hatching probably makes it possible to effectively receive oily and pasty meals from parents in a short time, using the peculiar flush feeding which is highly advanced in Procellariidae. Early completion of tarsus development may also allow them to be sandy burrow dwellers in windy erosive coasta lareas, because parents left them alone after a few days of hatching. Using the tarsus, they are not only able to protect themselves against burrow erosions caused by rain, wind or trampling by big animals during the absence of parents, but it also enables them to keep the body comfortable in burrows and to strengthen their leg muscles. Reared chicks vigourously began kicking the floor before three weeks of age (Oka, unpublished).

On the other hand the rapid development for flight-related parts, such as wings and tails began at the mid nestling period. However, this flight part development is considered to be more dependant on the nutritional level affected by the amount of meals given by parents than the bony organs which began developing before hatching. Chicks at the Clifton Bluff colony fledged with shorter wings and tails than those of adults in the summer of 1988 when they fledged with prominently lighter body waights than those in Bass Strait in 1980 (Lill \& Baldwin 1983) and 1982 (Fitzerbert 1985) ( $t$-test, $p<0.001$ ). As those flight parts continued to develop after fledging, as was shown in this study, the delayed and prolonged growths of these parts might, especially in a poor year, provide serious risks for the fledglings when migrating long distances to the northern North Pacific soon after leaving their burrows, because its growth possibly reduced the body lipids which should be left for migration energy in passing the tropical and sub-tropical waters with poor biomass. However, the growth rotation in organs and the prolonged nestling period, as a whole, may be adaptations to lower the maximum growth energy against the starvation.

Postfledging survival probably depends on the substantial fat reserves in their natal burrows. Fledglings from Clifton Bluff colony in 1988, like chicks at other colonies in Southern Tasmania (pers. obs.), suffered from nutritional deficiencies. Their daily weight loss just before fledging was about $7 \mathrm{~g}$ which excluded the energy consumption required for long locomotion. They had only $220 \mathrm{~g}$ heavier than the average body weight of dead shearwaters of $290 \mathrm{~g}$ (Oka \& Maruyama 1986). Therefore they probably had difficulty flying long distances to the north.

The marked increases of body weight around April 10 were caused by the parent's final and simultaneous feeding activity (Oka, unpublished). This simultaneous feeding activity and its cessation suggest that some of the adult population at the same colony 
set out to migrate to the north coincidently. Overweight. followed by desertion, and synchronizations of hatching and fledging in this species are possibly related to food availability highly biased to seasons, which, at the same time, might have stimulated this species developing a migration habitat for the optimal foraging strategy.

\section{Acknowledgements}

I am grateful to Mr. I. Skira of the Department of Parks, Wildlife and Heritage of Tasmania for obtaining permission from the Government to carry out the field work at Clifton Bluff in Tasmania and for obtaining bird bands from the Australian National Parks and Wildlife Service. I am indebted to Miss A. McCuaig of the same Department, Mrs. H. Okuyama, N. Kanzaki, T. Maeda of Tokyo Noko University and H. Naarding for assistance in the field. I am most grateful to Dr. N. Maruyama of Tokyo Noko University for contributing valuable suggestions on the manuscript and for his encouragement throughout the study. I also thank Drs K. Sone of the Forestry Institute, Japan and N. Kuroda of Director of the Yamashina Institute for Ornithology for helpful comments on the manuscript. I wish to thank Mr. R. Keenan of the Forestry Commission, Tasmania for his help in reviewing the English of the manuscript and Dr. K. Nishimura of Tsukuba University for his contribution to the mathematical analysis. This study was partly financed by the Toyota Foundation.

\section{References}

Bechard, M. J., Zoellick, B. W. \& Nicherson, M. 1985. Accuracy in Determining the Age of Nestling Red-tailed Hawks. J. Wildl. Manage. 49: 226-228.

Bureau of Meteorology, Australia. 1975. Climate of Hobart.

Drycz, A. 1974. Factors Affecting the Growth Rate of Nestling Great Reed Warblers and Reed Warblers at Milicz, Poland. Ibis 116: 330-339.

Evans, R. M. 1980. Development of Behavior in Seabirds: An Ecological Perspective. In Behavior of Marine Animals, Vol. 4: 271-322. Plenum Press.

Fitzherbert, K. 1985. The Role of Energetic Factors in the Evolution of the Breeding Biology of the Short-tailed Shearwater (Puffinus tenuirostris, Temminck). Ph. D. Thesis of Monash University.

Lack, D. 1968. Ecological Adaptations for Breeding in Birds. London, Methuen.

Lill, A. \& Baldwin, J. 1983. Weight Changes and the Mode of Depot Fat Accumulation in Migratory Short-tailed Shearwaters. Aust. J. Zool. 31: 891-902.

Naarding, H. 1981. Study of the Short-tailed Shearwater Puffinus tenuirostris in Tasmania. Nat. Parks \& Wildl. Serv. Tasmania.

Nice, M. M. 1962. Development of Behavior in Precocial Birds. Trans. Linn. Soc. N. Y. 8: 1-211.

Oka, N. \& Maruyama, N. 1986. Mass Mortality of Short-tailed Shearwaters along the Japanese Coast. Tori 34: 97-104.

Oka, N. \& Maruyama, N., Jida, N. \& Kuroda, N. 1986. Preliminary Study of Chick Growth of Short-tailed Shearwater in Tasmania. In Synthetic Study of the Mass Mortality of Short-tailed Shearwaters Puffinus tenuirostris: 90-100. (in Japanese). Abiko, Japan.

Oka, N., Maruyama, N. \& Skira, I. 1987. Chick Growth and Mortality of Short-tailed Shearwaters in Comparison with Sooty Shearwaters, as a Possible Index of Fluctuations of Australian Krill Abundance. Proc. NIPR Symp. Polar Biology, 1: 166-174. Nat. Inst. Polar Res., Tokyo.

Ricklefs, R. E. 1968. Patterns of Growth in Birds. Ibis 110: 419-451.

Ricklefs, R. E. 1973. Patterns of Growth in Birds, II; Growth Rate and Mode of Development. Ibis 
115: 177-201.

Ricklefs, R. E., White, S. \& Cullen, J. 1980. Postnatal Development of Leach's Storm-petrel. Auk 97: 768-781.

Serventy, D. L. 1967. Aspects of the Population Ecology of the Short-tailed Shearwater Puffinus tenuirostris. Proc. XIV Int. Orn. Congr.: 165-190 Oxford.

\section{タスマニアにおけるハシボソミズナギドリ Puffinus tenuirostris の雊の成長と発育}

1. 1988 年 1 月中旬から 4 月末日までオーストラリア・タスマニア州南東部南緯 43 度の Clifton Bluff コロニーでハシボソミズナギドリ雛の外部成長を卯化から巣立ちまで調查した。巣立ち成功率は全体で 35\%となり，雛の死亡の $73 \%$ が密猟と野猫の捕食によるものであり，この捕食は育觹中期から後期にか けて集中した。

2. 雛の餒化は 1 月 10-25 日にみられ，特に 16-21 日に集中した。巣立ちに先立ち雛は 4 月半ばから, 平均 9 日間夜間巣穴の出入りを繰り返した。巣立ちは4月15日，91日龃に始まり4月 23-29日に集中 し, 平均巣立ち日㱓は97日であった。

3. 餒化時の平均体重，ふ跚骨長，嘴峰長はそれぞれ親鳥の $10 \% ， 40 \% ， 50 \%$ であっだ。ふ蹠骨長の 成長率は餒化直後に，また嘴峰長の成長率は 1 週間齢でそれぞれ最大值を示し，育篗中期には親鳥サイズ となった。平均体重は育雛中期に親鳥の平均体重に達し，70 日齢から80日齡に顕著な增減を示した。60 日齢から83 日齢までの体重ピーク時には親鳥のほぼ15\% 増を示した。その後体重は減少を続け, ピーク 時の $25 \%$ 減, 親鳥比 $13 \%$ 減で巣立った。一方, 風切羽, 尾羽はそれぞれ 34, 45 日齡で伸長を始め, 骨 部位とは対照的にその成長は育雊後半期に集中し，成長率は翼長，尾長ともに60日齢で最大值を示した。 しかし，翼長，尾羽は巣立ち時には親鳥サイズには到達せず，巣立ち後も伸長することが示唆された。

4. 单立ちに平均 97 日を要する亜遅成性本種雛の成長様式の適応性を, 体部位の成長期のずれに焦点 をあてて論議し, あわせて体重成長の年次変化からその後の生残の可能性について論議した。

岡 奈理子：山階鳥類研究所, 研究部, 干270-11 我棌子市高野山堤根 115 